\title{
Implementasi Research Based Learning (RBL) pada Mata Kuliah IPA Terpadu di Program Studi Pendidikan Fisika
}

\author{
Fanny Rahmatina Rahim \\ Staf Pengajar Jurusan Fisika, FMIPA Universitas Negeri Padang \\ fannyrahmatina@fmipa.unp.ac.id
}

\begin{abstract}
To help realize UNP's vision towards a research-based university, awareness of Educators is needed to be active in providing innovation in classroom learning such as transforming conventional learning into research-based learning. This aim of this study was to analyze the implementation of research-based learning in Integrated Science courses Class VII in an effort to improve the ability to think critically and creatively. The study used the Quasi Experimental Research method with the design of the Pretest-posttest Control Group Design. The study was conducted in two sample classes obtained from cluster random sampling techniques by providing research-based learning treatment to the experimental class and ordinary learning to the control class. The research data was pre-test and post-test instrument, student response questionnaire and observation sheet during the learning process. With the implementation of research-based learning, the ability to think critically and creatively students of Physics Education FMIPA UNP was expected to be able to increase.
\end{abstract}

Keywords : Research based learning, Integrated science learning

(i) This is an open access article distributed under the Creative Commons 4.0 Attribution License, which permits unrestricted use, distribution, and reproduction in any medium, provided the original work is properly cited. $@ 2018$ by author and Universita s Negeri Padang.

\section{PENDAHULUAN}

Hakekat pendidikan menurut UNESCO mengintegrasikan empat pilar pendidikan, yaitu learning to know, learning to do, learning to be, dan learning to live together. Learning, yang artinya pembelajaran merupakan suatu proses pengintegrasian berbagai komponen yang tersusun dari unsur manusiawi, material, fasilitas, perlengkapan, dan prosedur (Hamalik, 2011: 42) dan kegiatan, yaitu peserta didik dan lingkungan belajar agar diperoleh suatu perubahan tingkah laku ke arah yang lebih baik (Mulyasa, 2009: 255) sesuai dengan tujuan yang diharapkan (Rusman, 2011: 116). Agar dapat berjalan dengan baik, pembelajaran semestinya dirancang secara efektif dan efisien dengan melakukan inovasi model pembelajaran.

Salah satu mata kuliah yang ada di prodi Pendidikan Fisika adalah IPA Terpadu yang bertujuan untuk menghasilkan calon guru yang kritis dan kreatif, serta terampil dalam menelaah konsep dan prinsip IPA. Mata kuliah ini mengintegrasikan konsep Fisika, Kimia, dan Biologi ke dalam satu kesatuan konsep ilmu (Sari, 2018). Salah satu ciri utama dalam pembelajaran IPA Terpadu adalah pembelajaran sistematis yang dimulai dari fakta, konsep, prinsip, hingga prosedur yang sejalan dengan kegiatan riset.
Agar pembelajaran IPA Terpadu dapat berjalan secara efektif, dibutuhkan upaya pendidikan untuk membantu peserta didik dalam melakukan kegiatan pembelajaran (Isjoni, 2012: 11), diantaranya adalah dengan menerapkan Pembelajaran Berbasis Riset (Research Based Learning/ RBL).

Riset merupakan cara penting untuk meningkatkan mutu pembelajaran melalui proses pengumpulan, analisis, dan interpretasi data secara sistematis untuk meningkatkan pemahaman tentang fenomena yang diminati (Leedy, 2010: 2). Komponen riset terdiri dari latar belakang, prosedur, pelaksanaan, hasil riset, dan pembahasan serta publikasi hasil riset. Komponen riset ini kemudian dikembangkan menjadi sebuah model pembelajaran yang disebut RBL.

RBL pertama kali dikembangkan di Griffith University (2008). RBL didasari filosofi konstruktivisme. Filosofi konstruktivisme menuntut agar mahasiswa mampu memiliki kontribusi aktif terhadap proses belajar dengan membangun pengetahuannya sendiri dengan cara mengkombinasi antara informasi baru dan pengalaman dengan struktur pengetahuan yang sudah ada di dalam pikiran mereka. Artinya, konsep baru yang dipelajari siswa harus sesuai dengan keterampilan siswa dan dikaitkan dengan 
konsep-konsep yang sudah mereka miliki sebelumnya (Gazali, 2018). Filosofi konstruktivisme pembelajaran berbasis riset adalah membangun pemahaman mahasiswa, mengembangan prior knowlodge, meningkatkan interaksi sosial, dan memunculkan pembelajaran bermakna.

RBL merupakan student-centered learning yang memberikan peluang kepada mahasiswa untuk "learning by doing" sehingga pembelajaran menjadi lebih bermakna. Arifin (2010) menyatakan dengan RBL, mahasiswa dapat 1) memahami konsep dasar dan metodologi yang kuat, 2) memecahkan masalah secara kreatif, logis, dan sistematis, 3) mempunyai sikap ilmiah yang selalu mencari kebenaran, terbuka, dan jujur. Ketiga hal tersebut dapat tercapai apabila melaksanakan RBL sesuai dengan komponen riset. Komponen RBL terdiri dari latar belakang masalah, prosedur riset, pelaksanaan riset, hasil riset, pembahasan, dan publikasi hasil riset.

Secara umum, RBL bertujuan untuk menciptakan proses pembelajaran yang mengarah pada aktivitas analisis, sintesis, dan evaluasi serta meningkatkan kemampuan mahasiswa dan dosen dalam hal asimilasi dan aplikasi pengetahuan. Setelah RBL terlaksana dalam pembelajaran, mata kuliah menjadi lebih bermakna karena lebih bersifat kontekstual melalui pemaparan hasil-hasil penelitian, kemampuan mahasiswa sebagai calon peneliti menjadi lebih kuat, pembelajaran dipenuhi dengan internalisasi nilai-nilai penelitian, praktik, dan etika penelitian dengan cara melibatkan penelitian.

Mata kuliah IPA Terpadu pada hakikatnya merupakan mata kuliah yang mengarahkan calon guru untuk menyajikan materi Fisika, Biologi, dan Kimia secara terpadu. Untuk itu, diperlukan suatu model pembelajaran terpadu yang memungkinkan peserta didik baik secara individual maupun kelompok aktif mencari, menggali, dan menemukan konsep serta prinsip secara holistik dan otentik (Permatasari, 2013: 2). Dengan pembelajaran terpadu, peserta didik akan memahami konsep-konsep yang mereka pelajari melalui pengamatan langsung dan menghubungkan dengan konsep lain yang mereka pahami. Dalam pembelajaran IPA Terpadu, suatu tema dibahas dari sudut pandang atau kajian, baik biologi, fisika maupun kimia, sehingga peserta didik mempelajari sains secara keseluruhan (Rahayu, 2012: 2).

Palmer (Arlitasari, 2013: 82) menyatakan bahwa pembelajaran terpadu dapat meningkatkan pemahaman, ingatan, dan aplikasi. Pembelajaran terpadu dapat memberikan pengalaman yang bermakna bagi peserta didik karena dalam pembelajaran terpadu peserta didik akan memahami konsep-konsep yang dipelajari melalui pengalaman langsung. Pengalaman langsung dapat diperoleh oleh peserta didik melalui RBL.

Pelaksanaan RBL dalam perkuliahan IPA Terpadu dilakukan secara runtut sesuai dengan langkah-langkah riset seperti Gambar 1. 


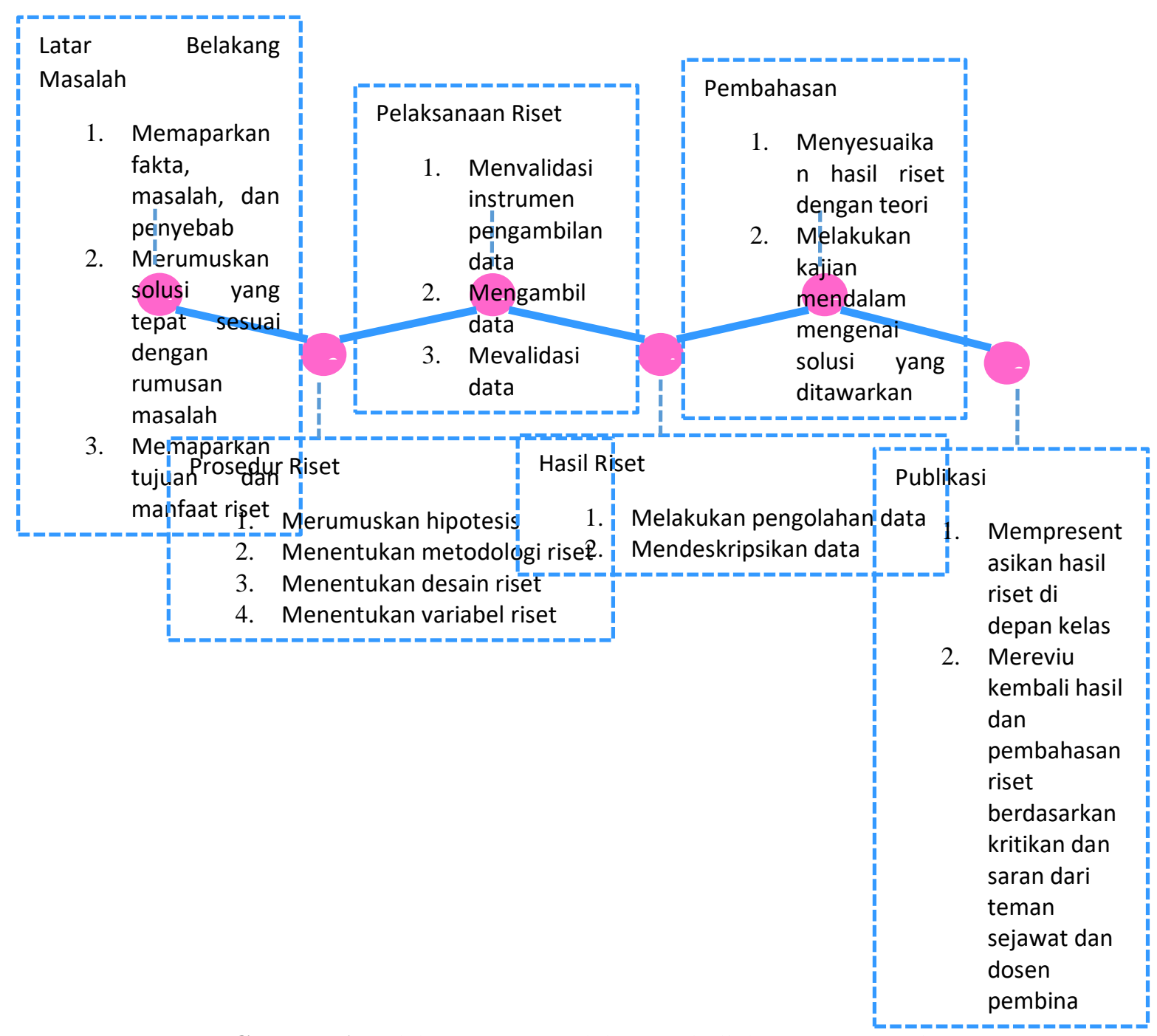

Gambar 1. Pelaksanaan RBL dalam Perkuliahan IPA Terpadu

Mahasiswa diharapkan mampu menelaah berbagai kasus dalam pembelajaran IPA Terpadu dan upaya strategis pemecahannya. Dengan demikian, kompetensi yang harus dimiliki oleh mahasiswa setelah mengikuti perkuliahan sangat terkait dengan kemampuan mahasiswa dalam menjalankan riset dan membangun kemampuan berpikir kritis dan kreatif. Santrock (2011: 357) menyatakan bahwa berpikir adalah memanipulasi atau mengelola dan mentransformasi informasi dalam memori. Berpikir sering dilakukan untuk membentuk konsep, bernalar, dan berpikir secara kritis, membuat keputusan, berpikir kreatif, dan memecahkan masalah.

Pemikiran kritis adalah pemikiran reflektif dan produktif, serta melibatkan evaluasi bukti. Berpikir kritis berarti proses mental yang efektif dan handal Jensen (2011: 195) dalam kegiatan menganalisis ide atau gagasan ke arah yang lebih spesifik, membedakannya secara tajam, memilih, mengidentifikasi, mengkaji dan mengembangkannya ke arah yang lebih sempurna (Wijaya, 2010: 72). Sapriya (2011: 87) mengatakan bahwa tujuan berpikir kritis ialah untuk menguji suatu pendapat atau ide, termasuk di dalamnya melakukan pertimbangan atau pemikiran yang didasarkan pada pendapat yang diajukan.

Terdapat ciri-ciri tertentu yang dapat diamati untuk mengetahui bagaimana tingkat kemampuan berpikir kritis seseorang. Ciri-ciri berpikir kritis menurut Wijaya (2010: 72-73) yang digunakan dalam penelitian ini (1) mengenal secara rinci bagian-bagian dari keseluruhan, (2) pandai medeteksi permasalahan, (3) mampu membedakan ide yang relevan dengan yang tidak relevan, (4) mampu membedakan fakta dengan diksi atau pendapat, (5) suka mengumpulkan data untuk pembuktian faktual, (6) mampu mengetes asumsi dengan cermat, (7) mampu mencari alternatif pemecahan terhadap masalah, ide, dan situasi, (8) mampu 
membuat hubungan yang berurutan antara satu masalah dengan masalah lainnya, (9) mampu menarik kesimpulan generalisasi dari data yang telah tersedia dengan data yang diperoleh dari lapangan, (10) mampu menggambarkan konklusi dengan cermat dari data yang tersedia, (11) mampu membuat prediksi dari informasi yang tersedia, dan (12) Mampu menarik kesimpulan dari data yang telah ada dan terseleksi.

Selain kemampuan berpikir kritis, mahasiswa juga diharapkan dapat meningkatkan kemampuan berpikir kreatif. Isaksen et al (Grieshober, 2004) mendefinisikan berpikir kreatif sebagai proses konstruksi ide yang menekankan pada aspek kelancaran, keluwesan, kebaruan, dan keterincian. Menurut McGregor (2007), berpikir kreatif adalah berpikir yang mengarah pada pemerolehan wawasan baru, pendekatan baru, perspektif baru, atau cara baru dalam memahami sesuatu. Sementara menurut Martin (2009), kemampuan berpikir kreatif adalah kemampuan untuk menghasilkan ide atau cara baru dalam menghasilkan suatu produk. Pada umumnya, berpikir kreatif dipicu oleh masalah-masalah yang menantang.

Sharp (Briggs dan Davis, 2008) mengidentifikasi beberapa aspek berpikir kreatif, yaitu kebaruan, produktivitas, dan dampak atau manfaat. Kebaruan merujuk pada strategi penyelesaian masalah yang bersifat unik. Kebaruan tidak harus dikaitkan dengan ide yang betul-betul baru, melainkan baru menurut siswa. Ketika siswa menemukan solusi masalah untuk pertama kalinya, ia telah menemukan sesuatu yang baru, setidaknya bagi dirinya sendiri. Produktivitas merujuk pada konstruksi sebanyak mungkin ide, tak peduli apakah ide itu baru atau tidak. Sedangkan dampak atau manfaat merujuk pada kebermanfaatan suatu ide. Dalam konteks pembelajaran, salah satu bentuk dampak tersebut adalah meningkatnya kepercayaan diri siswa setelah mampu menyelesaikan soal yang baru. Komponen dampak atau manfaat ini penting dikemukakan karena betapapun suatu produk dikategorikan baru, tetapi bila tidak bermanfaat atau bahkan merugikan, produk itu tidak dapat dikategorikan kreatif.

Berpikir kreatif dipandang dari sisi proses merupakan respon peserta didik dalam menyelesaikan masalah dengan menggunakan metode yang sesuai. Dipandang sebagai produk atau hasil, berpikir kreatif menekankan pada aspek kelancaran (fluency), keluwesan (flexibility), keaslian (originality), dan kemampuan menilai (evaluation). Munandar (2009:36) mengemukakan ciri-ciri pribadi kreatif, yaitu: imajinatif, mempunyai minat yang luas, mandiri dalam berpikir, penuh energi, percaya diri, berani mengambil resiko, dan berani dalam pendirian dan keyakinan. Ciri-ciri berpikir kreatif terlihat pada Tabel 1 (Rahim, 2019).

Tabel 1. Ciri-ciri Berpikir Kreatif

\begin{tabular}{|c|c|c|}
\hline No & Indikator & Sub Indikator \\
\hline 1 & $\begin{array}{l}\text { Kemampuan } \\
\text { berpikir lancar } \\
\text { (fluency) }\end{array}$ & $\begin{array}{l}\text { 1. Mempunyai banyak ide } \\
\text { dan gagasan } \\
\text { 2. Mempunyai banyak } \\
\text { pertanyaan } \\
\text { 3. Mempunyai banyak } \\
\text { alternatif jawaban dan } \\
\text { penyelesaian masalah }\end{array}$ \\
\hline 2 & $\begin{array}{l}\text { Kemampuan } \\
\text { berpikir luwes } \\
\text { (flexibility) }\end{array}$ & $\begin{array}{l}\text { 1. Mempunyai bermacam } \\
\text { pendekatan mengatasi } \\
\text { persoalan } \\
\text { 2. Tidak terpaku pada } \\
\text { pola pemikiran yang } \\
\text { lama } \\
\text { 3. Memiliki kemampuan } \\
\text { menyampaikan } \\
\text { berbagai macam ide } \\
\text { tanpa rasa takut salah } \\
\text { 4. Memberikan berbagai } \\
\text { macam penafsiran }\end{array}$ \\
\hline 3 & $\begin{array}{l}\text { Kemampuan } \\
\text { berpikir } \\
\text { orisinal } \\
\text { (originality) }\end{array}$ & $\begin{array}{l}\text { 1. Memiliki kemampuan } \\
\text { untuk melahirkan ide- } \\
\text { ide atau gagasan- } \\
\text { gagasan } \\
\text { 2. Mampu membuat } \\
\text { kombinasi-kombinasi } \\
\text { yang sifatnya baru dan } \\
\text { unik } \\
\text { 3. Menggunakan cara } \\
\text { yang tidak lazim dalam } \\
\text { mengungkapkan diri, } \\
\text { dan mampu mencari } \\
\text { berbagai kemungkinan } \\
\text { pemecahan masalah }\end{array}$ \\
\hline 4 & $\begin{array}{l}\text { Kemampuan } \\
\text { menilai } \\
\text { (evaluation) }\end{array}$ & $\begin{array}{l}\text { 1. Memberi pertimbangan } \\
\text { atas dasar sudut } \\
\text { pandangnya sendiri } \\
\text { 2. Menentukan pendapat } \\
\text { sendiri mengenai suatu } \\
\text { hal } \\
\text { 3. Menganalisa masalah } \\
\text { atau penyesalan secara } \\
\text { kritis dengan selalu } \\
\text { menanyakan } \\
\text { "Mengapa?" } \\
\text { 4. Mempunyai alasan } \\
\text { rasional yang dapat } \\
\text { dipertanggungjawab- } \\
\text { kan }\end{array}$ \\
\hline
\end{tabular}


Permasalahan di lapangan adalah perkuliahan IPA Terpadu belum berbasis riset. Hasil wawancara dengan dosen pengampu mata kulia IPA Terpadu menunjukkan mahasiswa masih menggunakan metode presentasi dalam pembelajaran. Mahasiswa belum melakukan penemuan ilmiah secara mandiri serta kurang kritis dan kreatif dalam menyelesaikan permasalahan yang kontekstual.

Oleh karena itu, pembelajaran pada mata kuliah IPA Terpadu sebaiknya dilaksanakan berbasis riset. RBL merupakan sistem pengajaran yang bersifat authentic problem solving dengan sudut pandang formulasi permasalahan, penyelesaian masalah, dan mengkomunikasikan manfaat hasil riset. Pembelajaran mengacu pada riset dalam upaya membangun kemampuan berpikir kritis dan kreatif mahasiswa.

RBL secara efektif meningkatkan proses pembelajaran (Umar, 2011; Fadriati, 2016; Serevina, 2015; Endriani, 2010). Hal ini terlihat dari kompetensi mahasiswa dalam merancang pembelajaran, melaksanakan pembelajaran serta memecahkan berbagai macam permasalahan yang terjadi di sekolah. RBL juga meningkatkan kemandirian mahasiswa dalam belajar. Selain itu, RBL memberikan manfaat yang sangat baik dalam perkembangan kualitas pembelajaran dengan cara meningkatkan kemampuan berpikir kritis dan kreatif mahasiswa (Rahim, 2018).

Kemampuan berpikir kritis adalah kemampuan untuk mengevaluasi secara sistematis bobot pendapat pribadi dan orang lain melalui kegiatan menganalisis ide atau gagasan ke arah yang lebih spesifik, membedakannya secara tajam, memilih, mengidentifikasi, mengkaji dan mengembangkannya ke arah yang lebih sempurna. Sedangkan kemampuan berpikir kreatif adalah kemampuan berpikir yang membutuhkan kemurnian (originality), dan ketajaman pemahaman (insight) dalam mengembangkan sesuatu (generating). Melalui RBL, mahasiswa berkesempatan meningkatkan dan mengembangkan kemampuan berpikir, terutama berpikir kritis dan kreatif. Pada akhirnya, kualitas pembelajaranpun juga akan meningkat.

Penelitian terdahulu melihat pengaruh RBL terhadap hasil belajar mahasiswa yang dilihat dari Indeks Prestasi Kumulatif (IPK). Inovasi dalam penelitian ini, penulis ingin melihat pentingnya RBL dalam meningkatkan kemampuan berpikir kritis dan kreatif. Oleh karena itu, penulis melakukan penelitian yang berjudul "Implementation of Research Based Learning In Integrated Science Learning In Physics Education Study Program ".

\section{METODE PENELITIAN}

Jenis penelitian ini adalah penelitian eksperimen semu (Quasi Experimental Research). Rancangan penelitian ini adalah Pretest-posttest Control Group Design. Rancangan penelitian dapat dilihat pada Tabel 2. Tabel 2. Bagan Rancangan Penelitian

\begin{tabular}{cccc} 
Eksperimen & $\mathrm{O}_{1}$ & $\mathrm{X}$ & $\mathrm{O}_{2}$ \\
Kontrol & $\mathrm{O}_{3}$ & - & $\mathrm{O}_{4}$ \\
\hline
\end{tabular}

Keterangan:

$\mathrm{O}_{1}$ : Data hasil pre-test pada kelas Eksperimen

$\mathrm{O}_{2}$ : Data hasil post-test pada kelas Eksperimen

$\mathrm{O}_{3}$ : Data hasil pre-test pada kelas Kontrol

$\mathrm{O}_{4}$ : Data hasil post-test pada kelas Kontrol

$\mathrm{X}$ : Perlakuan (RBL)

Populasi dalam penelitian ini adalah seluruh mahasiswa Pendidikan Fisika 2016 Jurusan Fisika Fakultas Matematika dan Ilmu Pengetahuan Alam Universitas Negeri Padang. Sampel yang digunakan diambil dengan menggunakan teknik cluster random sampling, dengan cara mengambil wakil dari setiap populasi yang ada. Dari kelompok yang didapat diambil dua kelompok sampel yang akan dijadikan kelas eksperimen dan kelas kontrol.

Variabel dalam penelitian ini terdapat pada Tabel 3.

Tabel 3. Variabel Penelitian

\begin{tabular}{lcc}
\hline $\begin{array}{l}\text { Variabel } \\
\text { Kontrol }\end{array}$ & $\begin{array}{c}\text { Variabel } \\
\text { Bebas }\end{array}$ & Variabel Terikat \\
\hline 1. Dosen & Pembelaja & 1. Kemampuan \\
pengampu & -ran & berpikir \\
mata kuliah & berbasis & kritis \\
2. Bahan ajar & riset & 2. Kemampuan \\
berpikir \\
3. Kondisi & & kreatif \\
kelas & & \\
4. Lamanya & & \\
waktu & & \\
perkuliaha & & \\
n & & \\
\hline
\end{tabular}

Data dalam penelitian ini adalah data kemampuan berpikir kritis dan kreatif mahasiswa Pendidikan Fisika 2016 Jurusan Fisika FMIPA UNP setelah perlakuan diberikan, berupa data primer yaitu data yang diperoleh langsung dari sampel yang diteliti. 


\section{HASIL DAN PEMBAHASAN}

Penelitian ini dilaksanakan di kelas Pendidikan Fisika, Jurusan Fisika, Universitas Negeri Padang. Materi yang diajarkan saat penerapan RBL adalah materi pencemaran lingkungan. Materi ini menjadi materi yang sangat menarik untuk dikaji karena menjadi isu yang mutakhir sebagai salah satu permasalahan yang dihadapi oleh semua orang di dunia. Untuk menfasilitasi penerapan RBL, pengumpulan data, dan menjaga privasi dari subjek yang diteliti, maka peneliti menggunakan kode nama untuk masing-masing mahasiswa. Kode nama terdiri dari huruf dan angka. Huruf menunjukkan kode kelas dan angka menunjukkan kode Nomor Induk Mahasiswa (NIM).

Sebagai langkah awal untuk melihat pengaruh RBL terhadap kemampuan berpikir kritis dan kreatif mahasiswa, peneliti melakukan pretest berupa soal esai yang berhubungan dengan materi pencemaran lingkungan. Tes ini terdiri dari 10 (sepuluh) pertanyaan yang dilaksanakan selama 45 menit. Setelah tes berlangsung sesuai dengan waktu yang telah ditentukan, peneliti menelusuri kemampuan berpikir kritis dan kreatif mahasiswa lebih dalam lagi dengan melakukan wawancara kepada beberapa orang mahasiswa. Dalam kegiatan wawancara, peneliti meminta subjek penelitian untuk duduk senyaman dan setenang mungkin demi menghindari tekanan psikologis yang dapat berdampak pada jawaban wawancara. Dalam prosesnya, 5 (lima) orang mahasiswa berhasil diwawancarai dengan total waktu sekitar 25 menit.

Kemudian, mahasiswa melakukan kegiatan RBL sesuai dengan langkah yang dipaparkan pada Gambar 1. Pertama, mahasiswa memaparkan fakta pencemaran lingkungan sekitar. Kedua, dengan melakukan kajian literatur, mahasiswa mencari tahu penyebab dari pencemaran lingkungan dan memunculkan sebuah hipotesis. Ketiga, mahasiswa mengambil data dengan cara mengamati, mencatat, dan menganalisis keadaan lingkungan sekitarnya yang mengalami pencemaran. Peneliti membimbing mahasiswa untuk menuliskan indikator-indikator pencemaran yang perlu didata saat turun ke lapangan.

Untuk menunjang data pengamatan yang telah dikumpulkan, mahasiswa juga melakukan wawancara terhadap masyarakat yang tinggal di lingkungan tercemar tersebut. Masyarakat tersebut mencakup warga yang tinggal di sekitar lingkungan tercemar, petugas kebersihan, dan warga yang melewati lingkungan tercemar. Selama kegiatan ini berlangsung, mahasiswa diwajibkan untuk mendokumentasikan setiap data dan wawancara yang dilakukan.

Setelah pengambilan data, mahasiswa melakukan pengolahan dan pendeskripsian data. Langkah berikutnya adalah interpretasi data dan menyesuaikan hasil pengamatan dengan teori yang sudah didapatkan dari kajian literatur. Terakhir, mahasiswa diminta untuk membuat jurnal yang mempresentasikan hasil riset yang telah mereka lakukan.

Berikut cuplikan kegiatan RBL yang dilakukan oleh mahasiswa beserta hasil riset yang telah disusun dalam bentuk jurnal.

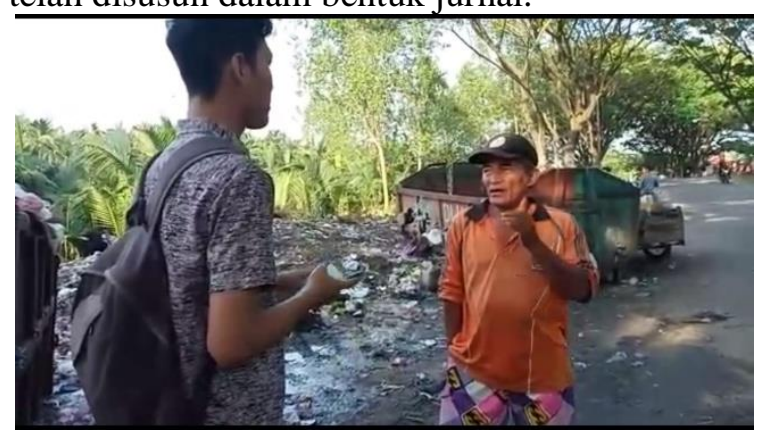

Gambar 2. Mahasiswa sedang mewawancari petugas kebersihan

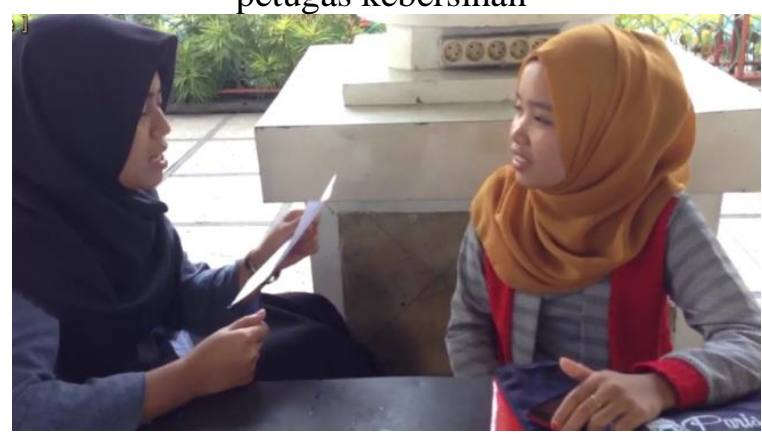

Gambar 3. Mahasiswa sedang mewawancari penduduk yang tinggal di sekitar lingkungan

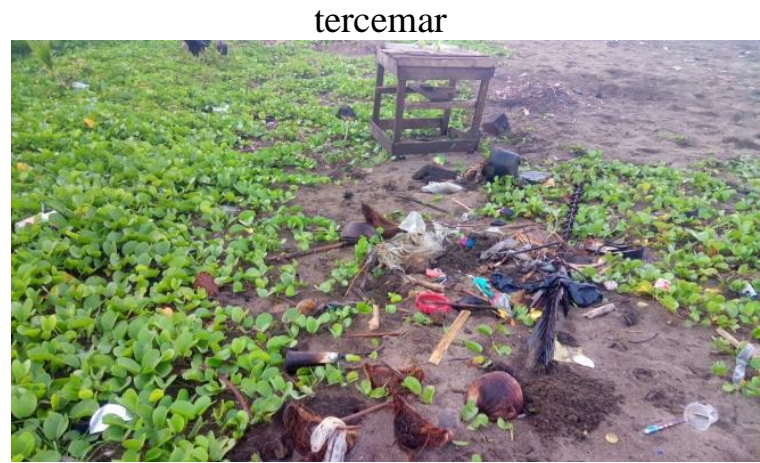

Gambar 4. Tanah yang dicemari oleh sampah 
Selama kegiatan RBL berlangsung, peneliti melakukan observasi untuk melihat proses penerapan RBL dalam pembelajaran dan respon mahasiswa dari semua rangkaian kegiatan. Peneliti menggunakan lembar observasi untuk mengamati kegiatan mahasiswa. Banyak mahasiswa yang menunjukkan kemampuan berpikir kritis dengan indikator banyak yang memberikan pertanyaan, berargumen saat diskusi, mendengarkan teman sekelompok saat diskusi, dan menggali lebih banyak informasi melalui artikel yang ada di internet. Fenomena ini sesuai dengan pernyataan Torrance dan Safter, "students prefer to learn creatively by exploring, questioning, experimenting, manipulating, listening, and testing. Reacting to powerful cultural forces, however, educational institutions encourage intelligence and logic, insisting that students learn by authority".

Setelah menerapkan RBL dalam pembelajaran IPA Terpadu, peneliti memberikan post-test kepada mahasiswa. Soal post-test terdiri dari 10 soal yang terdiri dari 5 soal untuk kemampuan berpikir kreatif dan 5 soal untuk kemampuan berpikir kritis.

Setelah diberikan post-test, penulis melakukan uji normalitas dan homogenitas pada kedua kelas yang terpilih menjadi kelas penelitian. Tabel 4 memperlihatkan distribusi data pada kelas kontrol adalah normal dengan nilai signifikansi sebesar 0,200 lebih besar dari 0,05 , sehingga dapat disimpulkan bahwa data terdistribusi normal. Tabel 5 memperlihatkan distribusi data pada kelas eksperimen adalah normal dengan nilai signifikansi sebesar 0,200 lebih besar dari 0,05 , sehingga dapat disimpulkan bahwa data terdistribusi normal. Sedangkan nilai homogenitas kelas kontrol dan eksperimen dapat dilihat pada Tabel 6 .

Tabel 4. Normalitas Nilai Post-Test Peserta Didik Kelas Kontrol

One-Sample Kolmogorov-Smirnov Test

\begin{tabular}{|c|c|c|}
\hline & & $X$ \\
\hline $\begin{array}{l}\text { N } \\
\text { Normal Parameters }{ }^{\mathrm{a}, \mathrm{b}}\end{array}$ & Mean & $\begin{array}{r}27 \\
34.99\end{array}$ \\
\hline & $\begin{array}{l}\text { Std. } \\
\text { Deviation }\end{array}$ & 5,715 \\
\hline $\begin{array}{ll}\text { Most } & \text { Extreme } \\
\text { Differences } & \end{array}$ & $\begin{array}{l}\text { Absolute } \\
\text { Positive }\end{array}$ & $\begin{array}{l}, 117 \\
, 117\end{array}$ \\
\hline
\end{tabular}

\begin{tabular}{|c|c|c|}
\hline $\begin{array}{l}\text { Test Statistic } \\
\text { Asymp. Sig. (2-tailed) }\end{array}$ & Negative & $\begin{array}{r}-, 054 \\
, 117 \\
, 200^{\mathrm{c}, \mathrm{d}}\end{array}$ \\
\hline
\end{tabular}

a. Test distribution is Normal.

b. Calculated from data.

c. Lilliefors Significance Correction.

$d$. This is a lower bound of the true significance.

Tabel 5. Normalitas Nilai Post-Test Peserta Didik Kelas Eksperimen

One-Sample Kolmogorov-Smirnov Test

\begin{tabular}{|c|c|c|}
\hline & & $\mathrm{Y}$ \\
\hline $\mathrm{N}$ & & 19 \\
\hline Normal Parameters ${ }^{\mathrm{a}, \mathrm{b}}$ & Mean & 39,01 \\
\hline & Std. & 5,138 \\
\hline & Deviation & 5,130 \\
\hline Extreme & Absolute &, 070 \\
\hline Differences & Positive & ,070 \\
\hline & Negative &,- 068 \\
\hline Test Statistic & &, 070 \\
\hline Asymp. Sig. (2-tailed) & & $200^{\mathrm{c}, \mathrm{d}}$ \\
\hline
\end{tabular}

a. Test distribution is Normal.

b. Calculated from data.

c. Lilliefors Significance Correction.

$d$. This is a lower bound of the true significance.

Tabel 6. Homogenitas Nilai Pre-Test Peserta Didik

Nilai
\begin{tabular}{|l|r|r|r|c|c|}
\hline & $\begin{array}{r}\text { Sum of } \\
\text { Squares }\end{array}$ & df & $\begin{array}{c}\text { Mean } \\
\text { Square }\end{array}$ & F & Sig. \\
\hline $\begin{array}{l}\text { Between } \\
\text { Groups } \\
\text { Within } \\
\text { Groups } \\
\text { Total }\end{array}$ & $\begin{array}{r}180,706 \\
1324,24\end{array}$ & 1 & 180,70 & 6,004 &, 018 \\
5 & 44 & 30,096 & & \\
1504,95 & 45 & & & \\
1 & 45 & & & \\
\hline
\end{tabular}

diketahui bahwa nilai signifikansi variabel kemampuan awal berdasarkan variabel kelas kontrol dan eksperimen adalah sebesar 0,018 lebih kecil dari 0,05, artinya data variabel kemampuan awal kelas kontrol dan eksperimen mempunyai varian yang tidak sama atau tidak homogen.

Setelah itu, peneliti melakukan uji varians kelas sampel untuk mengetahui apakah kelas kontrol dan eksperimen memiliki perbedaan awal atau tidak. Data ditampilkan pada Tabel 7. 
Tabel 7. Uji Beda Nilai Pre-Test Peserta Didik

\begin{tabular}{|c|c|c|c|c|c|c|c|c|c|}
\hline \multicolumn{10}{|c|}{ Independent Samples Test } \\
\hline & \multicolumn{2}{|c|}{$\begin{array}{c}\text { Levene's } \\
\text { Test for } \\
\text { Equality } \\
\text { of } \\
\text { Variances }\end{array}$} & \multicolumn{7}{|c|}{ t-test for Equality of Means } \\
\hline & \multirow[b]{2}{*}{$\mathrm{F}$} & \multirow[b]{2}{*}{ Sig. } & \multirow[b]{2}{*}{$\mathrm{t}$} & \multirow[b]{2}{*}{$\mathrm{df}$} & \multirow{2}{*}{$\begin{array}{l}\text { Sig. } \\
(2- \\
\text { tailed) }\end{array}$} & \multirow{2}{*}{$\begin{array}{c}\text { Mean } \\
\text { Difference }\end{array}$} & \multirow{2}{*}{$\begin{array}{l}\text { Std. Error } \\
\text { Difference }\end{array}$} & \multicolumn{2}{|c|}{$\begin{array}{l}\text { 95\% Confidence } \\
\text { Interval of the } \\
\text { Difference }\end{array}$} \\
\hline & & & & & & & & Lower & Upper \\
\hline $\begin{array}{ll}\text { Nilai Equal variances } \\
\text { assumed }\end{array}$ & ,229 & 635 & $-2,450$ & 44 & ,018 & $-4,025$ & 1,643 & $-7,336$ &,- 715 \\
\hline $\begin{array}{l}\text { Equal variances } \\
\text { not assumed }\end{array}$ & & & $-2,497$ & 41,309 & ,017 & $-4,025$ & 1,612 & $-7,280$ &,- 770 \\
\hline
\end{tabular}

Berdasarkan Tabel 7, nilai Sig. (2-tailed) sebesar 0,018 lebih kecil dari 0,05. Karena nilai tersebut lebih kecil dari 0,05 maka terdapat perbedaan bermakna secara statistik atau signifikan pada probabilitas 0,05 . Hal ini berarti setelah diterapkan RBL pada kelas eksperimen, terdapat perbedaan yang berarti terhadap hasil belajar mahasiswa kelas kontrol dan eksperimen yang berdampak pada perbedaan kemampuan berpikir kritis dan kreatif mahasiswa.

Secara umum, kemampuan berpikir kreatif mahasiswa sudah mulai terbentuk dengan baik sejak diterapkannya RBL. Selama proses RBL berlangsung di kelas, mahasiswa terbantu untuk memahami masalah dengan baik dan memanfaatkan sikap ilmiah untuk memecahkan masalah. Mahasiswa tidak lagi menganggap IPA Terpadu sebagai mata kuliah hafalan, tetapi sebagai mata kuliah yang dapat diterapkan dalam kehidupan sehari-hari.

Arifin (2010) menyatakan dengan RBL, mahasiswa dapat 1) mempunyai pemahaman konsep dasar dan metodologi yang kuat, 2) dapat memecahkan masalah secara kreatif, logis, dan sistematis, 3) mempunyai sikap ilmiah yang selalu mencari kebenaran, terbuka, dan jujur. Selain itu, indikator kemampuan berpikir kreatif mahasiswa juga terbentuk. Pada indikator berpikir lancar, mahasiswa dapat menyelesaikan permasalahan dengan lebih dari satu cara. Pada indikator berpikir luwes, mahasiswa dapat menginterpretasikan data yang diberikan. Pada indikator berpikir orisinal, mahssiwa dapat mensintesis lebih dari satu konsep menjadi konsep baru. Kemudian, pada indikator kemampuan menilai, mahasiswa dapat memberikan pertimbangan dan menganalisis permasalahan sains dengan berbagai alasan.
Begitu juga dengan kemampuan berpikir kritis mahasiswa. Selama proses pembelajaran berlangsung, mahasiswa sudah memikirkan permasalahan dan solusi terhadap permasalahan tersebut dengan kritis. Untuk mencari solusi, mereka mencari informasi sebanyak-banyaknya penyebab terjadinya masalah tersebut kemudian mengkaji secara mendalam. Hal ini selaras dengan pendapat Wijaya (2010: 72) bahwa kemampuan berpikir kritis merupakan kegiatan menganalisis ide atau gagasan ke arah yang lebih spesifik, membedakannya secara tajam, memilih, mengidentifikasi, mengkaji dan mengembangkan nya ke arah yang lebih sempurna.

Ada beberapa hal yang dapat dikembangkan untuk meningkatkan kemampuan berpikir kritis dan kreatif mahasiswa, yaitu: (1) mengarahkan mahasiswa untuk mengangkat masalah yang spesifik, menarik, dan dapat dilakukan penyelidikan, (2) meminta siswa merancang dinamika penyelidikan yang orisinil hasil pemikiran individu atau kelompok untuk membuktikan sebuah hipotesis, (3) mengemas proses pembelajaran yang membebaskan mahasiswa menggali sendiri konsep-konsep yang ada di dalam literatur, memperbaiki miskonsepsi, dan memberikan pengayaan pada saat diskusi kelas, (4) mengarahkan mahasiswa untuk menyajikan hasil penyelidikan berupa tabel, grafik, dan lain-lain.

Seseorang yang memiliki kemampuan berpikir kritis tidak hanya mengenal sebuah jawaban tetapi juga mengembangkan kemungkinan-kemungkinan jawaban yang lain berdasarkan analisis dan informasi yang didapat. Berpikir kritis berarti melakukan proses penalaran terhadap suatu masalah sampai pada 
tahap kompleks tentang "mengapa" dan "bagaimana" proses pemecahannya.

Tanggapan mahasiswa terhadap penerapan RBL sangat penting untuk diketahui, karena melalui tanggapan mahasiswa sebagai pembelajar, maka akan diketahui apakah RBL ditanggapi positif atau negatif oleh mahasiswa. Angket tersebut terdiri dari 15 item pernyataan. Hasil angket tanggapa siswa terlihat pada Gambar 5.

Gambar 5 menunjukkan tanggapan positif mahasiswa terhadap penerapan RBL. Tanggapan mahasiswa terhadap penerapan Model RBL masuk kategori kuat sebesar $62 \%$ dan kategori sangat kuat sebesar $38 \%$.

\section{0\% Angket}

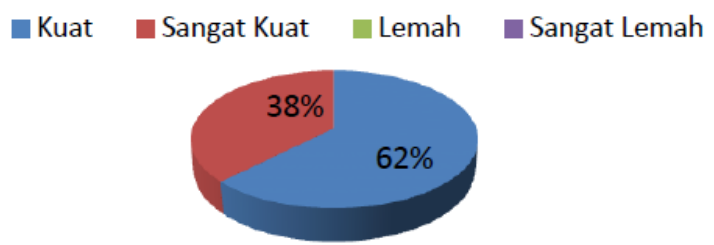

Gambar 5. Angket Respon Mahasiswa

Peningkatan kemampuan berpikir kritis dan kreatif mahasiswa diharapkan memberikan dampak yang baik bagi peningkatan kualitas pendidikan masa depan. Salah satu faktor penentu dari keberhasilan pendidikan di Indonesia adalah guru (Rahim, 2017). Oleh karena itu, perlu upaya yang berkesinambungan dalam mengembangkan dan meningkatkan kualitas pembelajaran yang dilalui oleh mahasiswa.

\section{KESIMPULAN}

Kesimpulan penelitian ini adalah terdapat pengaruh implementasi Research Based Learning terhadap kemampuan berpikir kritis dan kreatif mahasiswa. Indikatornya adalah adanya perbedaan yang signifikan hasil belajar mahasiswa kelas kontrol dan kelas eksperimen. Kemampuan berpikir kreatif dan kritis mahasiswa terbentuk dengan baik setelah melakukan kegiatan riset. Mahasiswa dapat memecahkan masalah secara kreatif, logis, dan sistematis dan berusaha untuk mencari solusi permasalahan dengan kritis.

\section{DAFTAR PUSTAKA}

Arifin, Pepen. 2010. Research Based Learning. Makalah Disampaikan Pada Simposium di Universitas Sebelas Maret, 28 Oktober 2010

Arifin, Pepen. 2010. Research Based Learning. Prosiding Seminar Nasional. Bandung: Institut Teknologi Bandung.

Arlitasari, Oni. 2013. Pengembangan Bahan Ajar IPA Terpadu Berbasis Salingtemas Dengan Tema Biomassa Sumber Energi Alternatif Terbarukan. Jurnal Pendidikan Fisika Vol. 1 No. 1 hal. 81 - 89

Briggs, M dan Davis, S. 2008. Creative Teaching Mathematics in the Early Years and Primary Classrooms. New York: Madison Ave

Endriani, Dewi. 2010. Peningkatan Kualitas Pembelajaran dan Kemandirian Mahasiswa Melalui Penerapan Strategi Kognitif dan Memberdayakan Mahasiswa Dalam Research-Based Learning. E-Journal of Unimed Vol. 3 No. 2 hal. 1- 22

Fadriati. 2016. Research-Based Learning Model With Interconnective Approach on PAI Learning Strategy. Proceeding International Seminar on Education Faculty of Tarbiyah and Teacher Training hal. $179-186$

Gazali, Fauzana; Yusmaita, Eka. 2018. Analisis Prior Knowledge Konsep Asam Basa Siswa Kelas XI SMA untuk Merancang Modul Kimia Berbasis REACT. JURNAL EKSAKTA PENDIDIKAN (JEP), [S.1.], v. 2, n. 2, p. 202-208, nov. 2018. ISSN 2579-860X.

Grieshober, W. E. 2004. Continuing a Dictionary of Creativity Terms \& Definition. New York: International Center for Studies in Creativity State University of New York College at Buffalo

Griffith Institute for Higher Education. 2008. Research Based learning : Startegies for Successfully linking teaching and research. University of Griffith

Hamalik, Oemar. 2011. Kurikulum dan Pembelajaran. Jakarta: Bumi Aksara

Isjoni. 2012. Cooperative Learning Efektifitas Pembelajaran Berkelompok. Bandung: Alfabeta 
Jensen. Eric. 2011. Brain-Based Learning. Yogyakarta: Pustaka Belajar

Leedy, Paul D. 2010. Practical Research Planning and Design Ninth Edition. New Jersey: Merrill Publisher

Martin. 2009. Thinking Skill in Psychology. [Online] Tersedia:

http://www.eruptingmind.com/converg ent-divergent-creative-thinking/ [13 Mei 2019]

McGregor, D. 2007. Developing Thinking Developing Learning. Poland: Open University Press

Mulyasa. 2009. Kurikulum Tingkat Satuan Pendidikan (KTSP). Bandung: Remaja Rosda Karya

Munandar, S.C Utami. 2009. Pengembangan Kreativitas Anak Berbakat. Jakarta: Rinka Cipta

Permatasari, Rizka. 2013. Pengembangan Bahan Ajar IPA Terpadu Tipe Webbed Dengan Tema Tanggap Bencana Untuk Siswa Kelas VII SMPN 1 Pogalan. Jurnal Pendidikan Sains e-Pensa Vol. 1 No. 2 hal. 47 - 51

Rahayu. 2012. Pengembangan Pembelajaran IPA Terpadu Dengan Menggunakan Model Pembelajaran Problem Base Melalui Lesson Study. Jurnal Pendidikan IPA Indonesia Vol. 1 No. 1 hal. $63-70$

Rahim, F R et al. 2019. A Preliminary Investigation Into Critical and Creative Thinking Skills of University Students in Integrated Science Class 7 Course. Journal of Physics: Conference Series. 1185012131 doi:10.1088/17426596/1185/1/012131

Rahim, Fanny Rahmatina et al. 2017. STUDI PENGALAMAN GURU-GURU MTSN 6 PESISIR SELATAN DALAM PENULISAN KARYA TULIS ILMIAH GUNA MENINGKATAN IPTEK
MASYARAKAT SERTA MEWUJUDKAN GURU YANG PROFESIONAL. JURNAL EKSAKTA PENDIDIKAN (JEP), [S.1.], v. 1, n. 2, p. 80-87, dec. 2017. ISSN 2579-860X.

Rahim, Fanny Rahmatina. 2018. Research Based Learning dalam Pembelajaran IPA Terpadu Untuk Meningkatkan Kemampuan Berpikir Kreatif Mahasiswa. SEMESTA: Journal of Science Education and Teaching, [S.1.], v. 1 , n. 2 , p. $32-38$, dec. ISSN 25981951

Rusman. 2011. Model-Model Pembelajaran. Jakarta: Rajagrafindo

Santrock, John W. 2011. Psikologi Pendidikan, Edisi Kedua. Jakarta: Kencana

Sapriya. 2011. Pendidikan IPS: Konsep dan Pembelajaran. Bandung: PT Remaja Rosdakarya

Sari, Silvi Yulia; DEWI, Wahyuni Satria. 2018. Kondisi Awal Perkuliahan IPA SMP/MTS Kelas IX dalam Rangka pengembangan Alat Peraga Berbasis Project Based Learning. JURNAL EKSAKTA PENDIDIKAN (JEP), [S.1.], v. 2, n. 2, p. 194-201, nov. 2018. ISSN 2579-860X

Serevina, Vina. 2015. The Development of Research Based Learning For Physics Education Students. Proseding Seminar Nasional Fisika dan Aplikasinya Universitas Padjajaran hal 25 - 33

Umar, dkk. 2011. Pengembangan Pembelajaran Berbasis Riset di Program Studi Pendidikan Fisika FMIPA Universitas Negeri Gorontalo. Laporan Hasil Penelitian

Wijaya, Cece. 2010. Pendidikan Remidial: Sarana Pengembangan Mutu sumber Daya Manusia. Bandung: PT Remaja Rosdakarya 